\title{
Stomatal and Mesophyll Limitations of Photosynthesis in Phosphate Deficient Sunflower, Maize and Wheat Plants
}

\author{
J. JACOB ${ }^{1}$ and D. W. LAWLOR \\ Department of Bıochemistry and Physıology, AFRC Institute of Arable Crops Research, Rothamsted Experimental Station, \\ Harpenden, Herts. AL5 2JQ, UK
}

Received 9 November 1990; Accepted 6 March 1991

\begin{abstract}
The effects of phosphate deficiency on the composition and photosynthetic $\mathrm{CO}_{2}$ assimilation rates of fully expanded leaves of sunflower, maize and wheat plants are described. The regulation of photosynthesis by stomatal and mesophyll characteristics of leaves of different phosphate status is analysed and related to structure. Phosphate deficient leaves had small concentrations of inorganic phosphate, $\mathrm{Pi}$, in the tissue water. Rate of photosynthesis in leaves and stomatal conductance were smaller in plants grown with inadequate phosphate when measured under any given light intensity or $\mathrm{CO}_{2}$ partial pressure. Despite the decrease in stomatal conductance (and without evidence of patchy stomatal closure), the relative stomatal limitation of photosynthesis was similar in the plants grown with deficient or abundant phosphate. However, the mesophyll capacity for photosynthesis was greatly limited by phosphate deficiency. Leaves deficient in phosphate had larger numbers of small size cells per unit leaf area than leaves with adequate phosphate. The total soluble protein content of leaves decreased with phosphate deficiency in all three species; however, the leaf chlorophyll content was decreased only in sunflower and maize and not in wheat. These results suggest that stomatal conductance did not restrict the $\mathrm{CO}_{2}$ diffusion rate, rather the metabolism of the mesophyll was the limiting factor. This is shown by poor carboxylation efficiency and decreased apparent quantum yield for $\mathrm{CO}_{2}$ assimilation, both of which contributed to the increase in relative mesophyll limitation of photosynthesis in phosphate deficient plants.
\end{abstract}

Key words: Apparent quantum yield, carboxylation efficiency, phosphate nutrition, photosynthesis, stomatal and mesophyll limitations.

\section{INTRODUCTION}

Phosphate is a major mineral nutrient for plants and a constituent of many structural and functional components in the cell; its importance for growth and metabolism has been reviewed by Clarkson and Hanson (1980) and Bieleski and Ferguson (1983). One of the most important effects of phosphate deficiency is in the reduction in the photosynthetic $\mathrm{CO}_{2}$ assimilation capacity of leaves and in decreasing the rates attained in particular environments (Terry and Ulrich, 1973). Orthophosphate deficiency in the chloroplasts may limit photosynthesis (Mächler, Schnyder, and Nösberger, 1984) by affecting translocation of carbon from the chloroplasts (Walker and Sivak, 1985; Sivak and Walker, 1986); inadequate supply of Pi prevents the efflux of triosephosphates from chloroplasts (Heldt and Rapley, 1970) and therefore synthesis of sucrose (Stitt, Huber, and Kerr, 1987). Phosphate deficiency also decreases the ATP supply and the rates of synthesis of RuBP, the substrate for carboxylation (Rao and Terry, 1989) and hence directly decreases $\mathrm{CO}_{2}$ assimilation by leaves. If there is insufficient phosphate in the cytosol, the reserve pool in the vacuole is mobilized to maintain the concentration required for metabolism. Thus the phosphate pools are in dynamic equilibrium though the details of its regulation are not well understood.

Phosphate deficiency decreased the $\mathrm{CO}_{2}$ assimilation by leaves reducing the carboxylation efficiency and apparent quantum yield (Brooks, 1986; Lauer, Pallardy, Blevins, and Randall, 1989) by its influence on metabolism and also by decreasing stomatal conductance (Rao and Terry, 1989). However, it is not clear if the main limitation to photosynthesis is in stomatal conductance or metabolic processes and details of the mechanisms by which phos-

\footnotetext{
${ }^{1}$ To whom correspondence should be addressed.
}

(C) Oxford University Press 1991 
phate deficiency affects $\mathrm{CO}_{2}$ assimilation are not well understood.

In the present investigations, we grew two $C_{3}$ species (sunflower and wheat) and one $\mathrm{C}_{4}$ species (maize) under different levels of phosphate supply, because the requirement of phosphate may depend on the type of metabolism. The effects of phosphate deficiency on the composition and $\mathrm{CO}_{2}$ assimilation characteristics of leaves are examined and we specifically analyse the effects of phosphate status of the leaf on photosynthetic rate and the contributions of stomatal and mesophyll components of the assimilatory system to it.

\section{MATERIALS AND METHODS}

\section{Plant material and growth conditions}

Hybrid sunflower (Helianthus annuus L. cv. Asmer), maize (Zea mays L. cv. ETA) and spring wheat (Triticum aestivum L. cv. Sicco) were sown in plastic pots containing washed sand. Three to four seeds were sown in each pot and germinated in a glasshouse. Pots were watered daily with demineralized water for 12-15 d and then moved to a controlled environment (CE) cabinet. The conditions during the light period were 350 $400 \mu \mathrm{mol}$ quanta $\mathrm{m}^{-2} \mathrm{~s}^{-1}$ photosynthetically active radiation $(400-700 \mathrm{~nm})$ for $16 \mathrm{~h}$, relative humidity $75-85 \%$ and air temperature $22{ }^{\circ} \mathrm{C}$; the night temperature was $20^{\circ} \mathrm{C}$ and relative humidity $85-90 \%$.

\section{Treatments}

One day after transferring the plants to the $\mathrm{CE}$ cabinet, nutrient solutions containing three different concentrations of phosphate were added to groups of plants. The contents of $\mathrm{KH}_{2} \mathrm{PO}_{4}$ and $\mathrm{NaH}_{2} \mathrm{PO}_{4}$ in standard nutrient solution (Edwards and Walker, 1983) were manipulated in such a way that the final solution had a concentration of $0,0.5$ or $10 \mathrm{~mol} \mathrm{PO}_{4}^{-} \mathrm{m}^{-3}$. Plants were supplied with the solution daily. Twice weekly the pots were flushed with excess demineralized water and drained to prevent accumulation of nutrients in the growth medium and then flushed with nutrient.

\section{Measurements}

Observations were made when the third true leaf attained full expansion.

Leaf Pi content: This was determined as described by Kitson and Mellon (1944). Concentration of $\mathrm{Pi}$ in the leaf water was calculated from measurements of $\mathrm{Pi}$ and the water content of the leaf. Total phosphate was estimated after digesting the leaf with a hot mixture of concentrated nitric and perchloric acids.

Leaf chlorophyll and soluble protein contents and cell size: Chlorophyll content was determined as described by Arnon (1949) and total soluble protein content of leaf as described by Bradford (1976). Mean leaf cell size was determined according to Lawlor, Kontturi, and Young (1989).

$\mathrm{CO}_{2}$ response and carboxylation efficiency: The response of photosynthesis to leaf internal partial pressure of $\mathrm{CO}_{2}, C_{\mathrm{i}}$, was studied as described by Lawlor et al. (1989). An asymptotic curve $\left(y=a+b r^{x}\right)$ was fitted to the $\mathrm{CO}_{2}$ response data since it gave very good coefficient of determination $\left(R^{2}\right)$. The $\mathrm{CO}_{2}$ saturated photosynthetic rate, $A_{\max \left(\mathrm{C}_{1}\right)}$, was obtained directly from the function $\left(A_{\max \left(\mathrm{C}_{t}\right)}=a\right)$. The carboxylation efficiency, $d A / d C_{\mathrm{i}}$, was calculated as the initial slope of the curve $(\mathrm{Ku}$ and Edwards, 1987) which was obtained by taking the differential quotient of $y=a+b r^{x}$ at $y=0$; i.e. $d y / d x=-a \ln r=d A / d C_{\mathrm{i}}$. This analysis assumes uniform stomatal behaviour in all treatments. The presence of stomatal closure in small areas of the leaf on which gas exchange was measured (patchiness) was tested by use of an infiltration method in which leaves were immersed in solutions of different proportions of ethanol and petroleum ether containing crystal violet or waxoline blue (Willis and Jefferies, 1963).

Light response and quantum yield: Photosynthetic response to varying photon flux density incident up on the leaf was studied using the above system. An asymptotic curve was fitted for the light response data. The apparent quantum yield for $\mathrm{CO}_{2}$ assimilation, $\phi$, defined as the initial slope of the curve when $y=0$ was then calculated as $\phi=-a \ln r$. The light saturated photosynthetic rate, $A_{\max (\text { light) }}$, was obtained directly from the function $\left(A_{\max (\text { Ight })}=a\right)$.

Relative stomatal and mesophyll limitations of photosynthesis: Relative stomatal limitation, $R S L$, was calculated from equation 13 of Farquhar and Sharkey (1982) as

$$
R S L=\frac{A_{\mathrm{o}}-A}{A_{\mathrm{o}}} \times 100
$$

where $A_{0}$ is the assimilation rate that would occur if resistance to $\mathrm{CO}_{2}$ diffusion were zero (i.e. when $C_{\mathrm{i}}=C_{\mathrm{a}}$, where $C_{\mathrm{a}}$ is the ambient concentration of $\mathrm{CO}_{2}$ ) and $A$ is the rate that actually occurs at the $C_{\mathrm{i}}$ corresponding to the normal $C_{\mathrm{a}}$. Since the sum of the limitations differs from unity (Farquhar and Sharkey, 1982) we defined relative mesophyll limitation, $R M L$, as

$$
R M L=\frac{A_{\mathrm{s}}-A_{\mathrm{d}}}{A_{\mathrm{s}}} \times 100
$$

where $A_{s}$ is the assimilation rate in the phosphate sufficient leaf at a given $C_{\mathrm{i}}$ and $A_{\mathrm{d}}$ is the rate in the phosphate deficient leaf at the same $C_{\mathrm{i}} . R M L$ is thus a measure of the capacity of the mesophyll to assimilate $\mathrm{CO}_{2}$ at a given $C_{\mathrm{i}}$. The $R M L$ of a leaf grown with full phosphate is, therefore, zero.

\section{RESULTS}

\section{Plant growth}

Phosphate nutrition significantly affected plant growth (Table 1). Phosphate deficiency reduced plant height by $52 \%$, leaf area per plant by $95 \%$ and shoot dry weight per plant by $93 \%$ in sunflower. The respective reductions were $57 \%, 89 \%$ and $90 \%$ in maize and $53 \%, 91 \%$, and $93 \%$ in wheat.

\section{Leaf composition}

Total and inorganic phosphate contents of the leaf decreased with decreasing concentration of phosphate in the nutrient solution (Table 2). The concentration of $\mathrm{Pi}$ in the leaf water decreased as the phosphate content per unit leaf area decreased.

Phosphate deficiency decreased the specific leaf weight by $17 \%$ in maize and $6 \%$ in sunflower, but had little effect in wheat (Table 3). Phosphate deficient leaves contained more and smaller cells per unit leaf area. The mean volume per cell was reduced by $31 \%$ in sunflower, $11 \%$ in maize and $9 \%$ in wheat. The leaf chlorophyll content decreased with phosphate deficiency in sunflower and maize and the mean chlorophyll content per cell decreased 
TA B LE 1. Effect of phosphate deficiency on plant growth in sunflower, maize and wheat

\begin{tabular}{|c|c|c|c|}
\hline $\begin{array}{l}\text { Concentration of } \mathrm{PO}_{4}^{-} \text {in } \\
\text { nutrient solution } \\
\left(\mathrm{mol} \mathrm{m}^{-3}\right)\end{array}$ & Plant height $(\mathrm{cm})$ & $\begin{array}{l}\text { Leaf area per } \\
\text { plant }\left(\mathrm{cm}^{2}\right)\end{array}$ & $\begin{array}{l}\text { Shoot dry matter } \\
\text { per plant }(\mathrm{g})\end{array}$ \\
\hline \multicolumn{4}{|l|}{ Sunflower } \\
\hline 10 & 46 & 895 & $6 \cdot 0$ \\
\hline 0.5 & 35 & 203 & 1.5 \\
\hline 0.0 & 22 & 41 & 0.4 \\
\hline $\operatorname{LSD}(P=0.05)$ & 2 & 45 & $0 \cdot 6$ \\
\hline \multicolumn{4}{|l|}{ Maize } \\
\hline 10 & 103 & 708 & $4 \cdot 0$ \\
\hline 0.5 & 93 & 405 & $2 \cdot 1$ \\
\hline $0 \cdot 0$ & 44 & 79 & $0 \cdot 4$ \\
\hline $\operatorname{LSD}(P=0.05)$ & 5 & 65 & $0 \cdot 6$ \\
\hline \multicolumn{4}{|l|}{ Wheat } \\
\hline 10 & 68 & 232 & $2 \cdot 8$ \\
\hline 0.5 & 48 & 30 & $1 \cdot 0$ \\
\hline $0 \cdot 0$ & 32 & 21 & $0 \cdot 2$ \\
\hline $\operatorname{LSD}(P=0.05)$ & 3 & 3 & 0.4 \\
\hline
\end{tabular}

TABLE 2. Effect of three different concentrations of phosphate in the nutrient solution on the total $P$ and Pi contents per unit leaf area and concentration of $P i$ in the leaf tissue water

\begin{tabular}{llll}
\hline $\begin{array}{l}\text { Concentration of } \mathrm{PO}_{4}^{-} \text {in } \\
\text { the nutrient solution } \\
\left(\mathrm{mol} \mathrm{m}^{-3}\right)\end{array}$ & $\begin{array}{l}\text { Total P content } \\
\text { of leaf } \\
\left(\mathrm{mmol} \mathrm{m}^{-2}\right)\end{array}$ & $\begin{array}{l}\text { Pi content } \\
\text { of leaf } \\
\left(\mathrm{mmol} \mathrm{m}^{-2}\right)\end{array}$ & $\begin{array}{l}\text { Concentration of Pi in leaf } \\
\text { tissue water } \\
\left(\mathrm{mol} \mathrm{m}^{-3}\right)\end{array}$ \\
\hline Sunflower & & & \\
10 & 7.20 & 1.65 & 7.81 \\
0.5 & 1.95 & 0.29 & 1.83 \\
0.0 & 1.81 & 0.21 & 1.20 \\
LSD $(P=0.05)$ & 1.08 & 0.22 & $1 \cdot 11$ \\
& & & \\
Maize & & 0.58 & 4.51 \\
10 & 4.80 & 0.19 & 1.60 \\
0.5 & 0.63 & 0.11 & 1.01 \\
0.0 & 0.51 & 0.14 & 0.89 \\
LSD $(P=0.05)$ & 0.88 & & \\
Wheat & & 0.65 & 4.00 \\
10 & 5.90 & 0.38 & 1.60 \\
0.5 & 1.83 & 0.21 & 1.21 \\
0.0 & 0.97 & 0.71 & 0.93 \\
LSD $(P=0.05)$ & 1.31 & & \\
\hline
\end{tabular}

by $36 \%$ and $45 \%$ in phosphate deficient sunflower and maize leaves, respectively. The ratio of the mesophyll surface area, $A_{\text {mes }}$, to the leaf plan area, $A_{\text {leaf }}$, calculated assuming that the mesophyll cells were spherical, slightly increased in the phosphate deficient sunflower $(8 \%)$ and maize $(9 \%)$ leaves, but not in wheat. Phosphate deficiency decreased the total soluble protein content of the leaves in all the three species.

\section{Stomatal conductance}

Stomatal conductance, $g_{s}$, decreased with phosphate deficiency in all the three species studied (Fig. 1b). Assessment of stomatal apertures by dye infiltration did not show any difference across the area of the leaf used for measuring gas exchange rates. Hence, we consider that stomatal aperture was not patchy in any treatment. Lauer et al. (1989) also reported similar results using autoradiographic techniques in soybean leaves grown with different levels of phosphate nutrition.

\section{Photosynthesis}

The $\mathrm{CO}_{2}$ assimilation rate, $A$, decreased strongly as the $[\mathrm{Pi}]$ in the leaf water decreased in the low phosphate treatments (Fig. 1a); however, the concomitant decrease in stomatal conductance, $g_{s}$, was small (Fig. 1 b) resulting in increased internal $\mathrm{CO}_{2}$ partial pressure, $C_{\mathrm{i}}$ (Fig. 1c) when measured under the normal ambient $\mathrm{CO}_{2}$ level of $34 \mathrm{~Pa}$. In phosphate deficient sunflower plants, $A$ was reduced by $79 \%, g_{\mathrm{s}}$ was reduced by $35 \%$ and $C_{\mathrm{i}}$ increased by $21 \%$. In maize, phosphate deficiency reduced $A$ by $88 \%, g_{\mathrm{s}}$ by $48 \%$ and increased $C_{\mathrm{i}}$ by $53 \%$. In phosphate deficient wheat $A$ was reduced by $26 \%, g_{s}$ by $46 \%$ and 
TABLE 3. Effect of phosphate deficiency on the leaf composition in sunflower, maize and wheat plants

\begin{tabular}{|c|c|c|c|c|c|c|c|}
\hline $\begin{array}{l}\text { Concentration of } \mathrm{PO}_{4}^{-} \text {in } \\
\text { nutrient solution } \\
\left(\mathrm{mol} \mathrm{m}^{-3}\right)\end{array}$ & $\begin{array}{l}\text { Specific leaf } \\
\text { weight } \\
\left(\mathrm{g} \text { fr. wt. } \mathrm{m}^{-2}\right)\end{array}$ & $\begin{array}{l}\text { Total } \\
\text { chlorophyll } \\
\text { content of } \\
\text { leaf }\left(\mathrm{g} \mathrm{m}^{-2}\right)\end{array}$ & $\begin{array}{l}\text { No. of cells } \\
\text { per } \mathrm{m}^{2} \text { leaf } \\
\text { area }\left(\times 10^{7}\right)\end{array}$ & $\begin{array}{l}\text { Mean } \\
\text { chlorophyll } \\
\text { content per } \\
\text { cell (ng cell }{ }^{-1} \text { ) }\end{array}$ & $\begin{array}{l}\text { Mean cell } \\
\text { volume } \\
\text { (pl) }\end{array}$ & $\frac{A_{\text {mes }}}{A_{\text {leaf }}}$ & $\begin{array}{l}\text { Total soluble } \\
\text { protein } \\
\text { content of } \\
\text { leaf }\left(\mathrm{g} \mathrm{m}^{-2}\right)\end{array}$ \\
\hline \multicolumn{8}{|l|}{ Sunflower } \\
\hline 10 & 235 & 0.56 & 723 & 0.078 & $27 \cdot 3$ & $31 \cdot 5$ & $12 \cdot 2$ \\
\hline 0 & 222 & 0.48 & 967 & $0-050$ & 18.9 & $34 \cdot 0$ & $6-7$ \\
\hline $\operatorname{LSD}(P=0.05)$ & 5 & 0.02 & 49 & 一 & $2 \cdot 6$ & $1 \cdot 4$ & $2 \cdot 6$ \\
\hline \multicolumn{8}{|l|}{ Maize } \\
\hline 10 & 145 & 0.42 & 152 & 0.276 & $42 \cdot 8$ & 8.9 & $5 \cdot 8$ \\
\hline 0 & 121 & 0.26 & 172 & 0.151 & $38 \cdot 0$ & $9 \cdot 7$ & $1 \cdot 1$ \\
\hline $\operatorname{LSD}(P=0.05)$ & 1 & 0.04 & 20 & - & $2 \cdot 3$ & 0.8 & $2 \cdot 2$ \\
\hline \multicolumn{8}{|l|}{ Wheat } \\
\hline 10 & 204 & 0.50 & 98 & 0.510 & 143.9 & $13 \cdot 6$ & $6 \cdot 28$ \\
\hline 0 & 201 & 0.54 & 105 & 0.514 & $131 \cdot 5$ & $13 \cdot 0$ & $5 \cdot 83$ \\
\hline $\operatorname{LSD}(P=0.05)$ & NS & NS & 5 & - & $11 \cdot 8$ & NS & 1.34 \\
\hline
\end{tabular}

NS $=F$ test not significant at $P=0.05$.
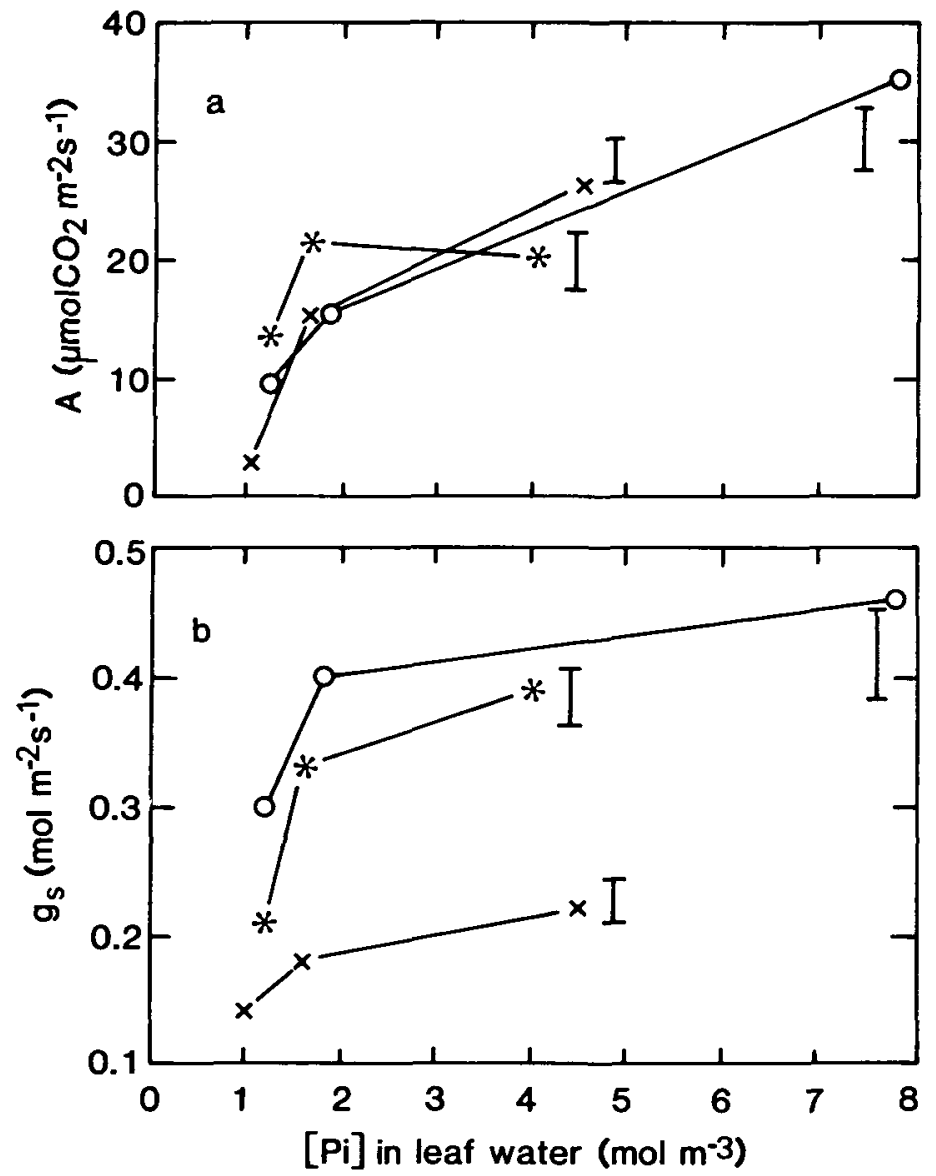

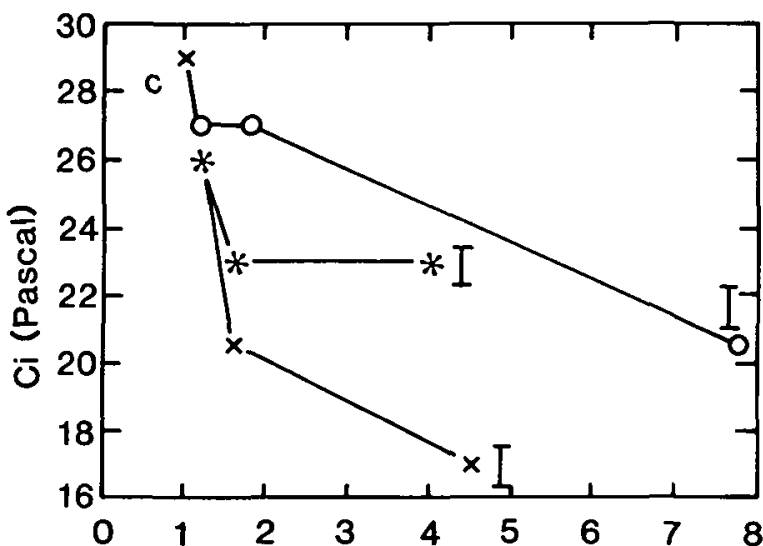

$[\mathrm{Pi}]$ in leaf water $\left(\mathrm{mol} \mathrm{m}^{-3}\right)$

Fig. 1. Effect of calculated Pi concentration in leaf water on $A(\mathrm{a}), g_{3}(\mathrm{~b})$ and $C_{\mathrm{i}}$ (c) in sunflower (O), maize (x) and wheat (*) under ambient conditions of $34 \mathrm{~Pa} \mathrm{CO}_{2}$ partial pressure and $1000 \mu \mathrm{mol}$ quanta $\mathrm{m}^{-2} \mathrm{~s}^{-1}$ photon flux. Bars indicate least significant difference between the means at $5 \%$ probability.

$C_{\mathrm{i}}$ increased by $13 \%$. An asymptotic curve $\left(A=a+b r^{C_{i}}\right)$ best fitted the $A . C_{\mathrm{i}}$ relationship in the three species grown with different levels of phosphate nutrition (Fig. 2a, b, c). The $C_{i}$ saturated photosynthetic rate, $A_{\max \left(C_{1}\right)}$, and the carboxylation efficiency, $d A / d C_{\mathrm{i}}$, were estimated from the fitted curves and are plotted against the [Pi] in leaf water in Fig. $3 a$ and $b$, respectively. The lower the [Pi] in leaf water, the lower the $A_{\max \left(\mathrm{C}_{1}\right)}$ in all the three species (Fig. 3a). The decrease in $A_{\max \left(\mathcal{C}_{1}\right)}$ between the 10 and $0 \mathrm{~mol} \mathrm{PO}_{4}^{-} \mathrm{m}^{-3}$ treatments was up to 3 times in sunflower, 

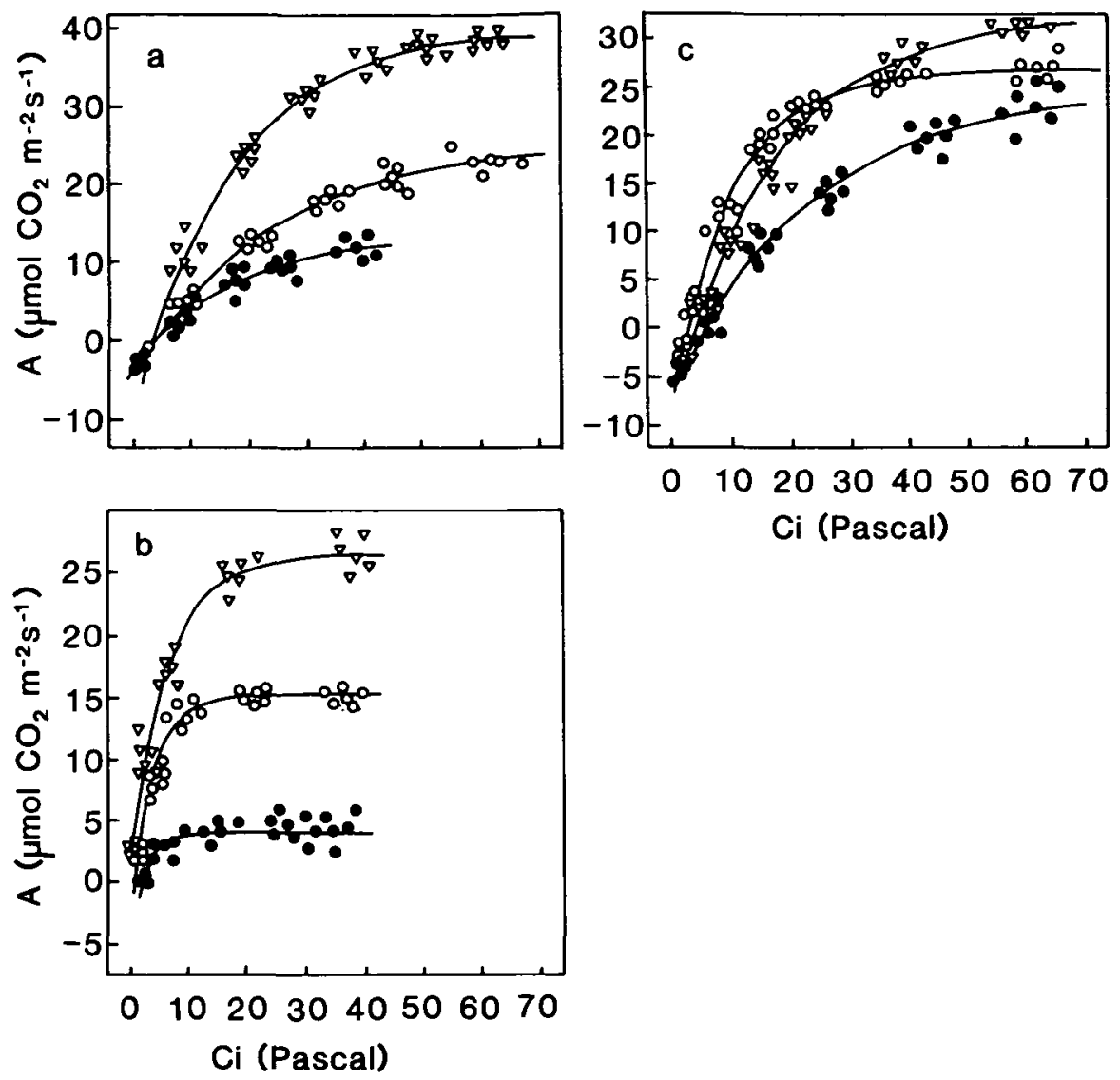

Fig. 2. Photosynthesis, $A$, as a function of internal partial pressure of $\mathrm{CO}_{2}, C_{\mathrm{i}}$, of leaves of sunflower (a), maize (b) and wheat (c) plants grown with $10(\nabla), 0.5(O)$ and $0(\Theta) \mathrm{mol} \mathrm{m}^{-3}$ phosphate concentrations. All curves are of the form $y=a+b r^{*}$ and the $R^{2}$ values in percentage in the respective phosphate treatments were 92,85 and 98 in sunflower, 90, 97 and 75 in maize and 97,87 and 95 in wheat.

5.3 times in maize and 1.4 times in wheat (Fig. 3a). There was a distinct difference in $d A / d C_{i}$ between the species (Fig. 3b), with maize having higher values than the other two species. The decrease in [Pi] in leaf water reduced $d A / d C_{\mathrm{i}}$ greatly in maize, but had much less effect on sunflower and wheat; the reduction was about 4.5 times in maize, 2.4 times in sunflower and $2 \cdot 1$ times in wheat (Fig. 3b).

The photosynthetic light response also followed an asymptotic relationship in the three species grown with different phosphate nutrition (Fig. 4a, b, c). The light saturated photosynthetic rate, $A_{\max (\text { light) }}$, and the apparent quantum yield for $\mathrm{CO}_{2}$ assimilation, $\phi$, were strongly decreased by a small [Pi] in leaf water (Fig. 5a, b) particularly in very deficient maize leaves; $A_{\max (\text { light })}$ was decreased by $24 \%$ in wheat, $40 \%$ in sunflower, but $83 \%$ in maize. The reduction in $\phi$ was about $44 \%$ in wheat, $48 \%$ in sunflower and $65 \%$ in maize.

\section{Relative stomatal and mesophyll limitations of photosynthesis}

The relative stomatal limitation, $R S L$, and relative mesophyll limitation, $R M L$, of photosynthesis were com- puted (Table 4) from the $A . C_{\mathrm{i}}$ response curves of 4-6 separate leaves. These calculations show that $R S L$ did not increase significantly with phosphate deficiency in any of the species. The $R M L$ (computed based on the assumption that the plants grown with $10 \mathrm{~mol} \mathrm{PO}_{4}^{-} \mathrm{m}^{-3}$ were photosynthesizing under optimum mesophyll conditions, i.e. $R M L=0$ ) was greater in plants grown with deficient phosphate nutrition. Both maize and sunflower exhibited a larger $R M L$ than wheat. $R M L$ increased drastically in phosphate deficient leaves of maize compared to sunflower and particularly to wheat-both at $34 \mathrm{~Pa}$ and saturating $C_{\mathrm{i}}$.

\section{DISCUSSION}

Phosphate, as the orthophosphate anion, $\mathrm{PO}_{4}^{-}$, is an essential nutrient for plants and provides the phosphorus required in many of the structural components of all living cells, e.g. phospholipids, phosphorylated proteins, nucleotides etc. Deficient phosphate supply throughout growth of the plant can, therefore, modify the structure of the cell. Phosphate is an essential component of the biochemical reactions of intermediary metabolism; its involvement in energy metabolism of cells as ATP particu- 

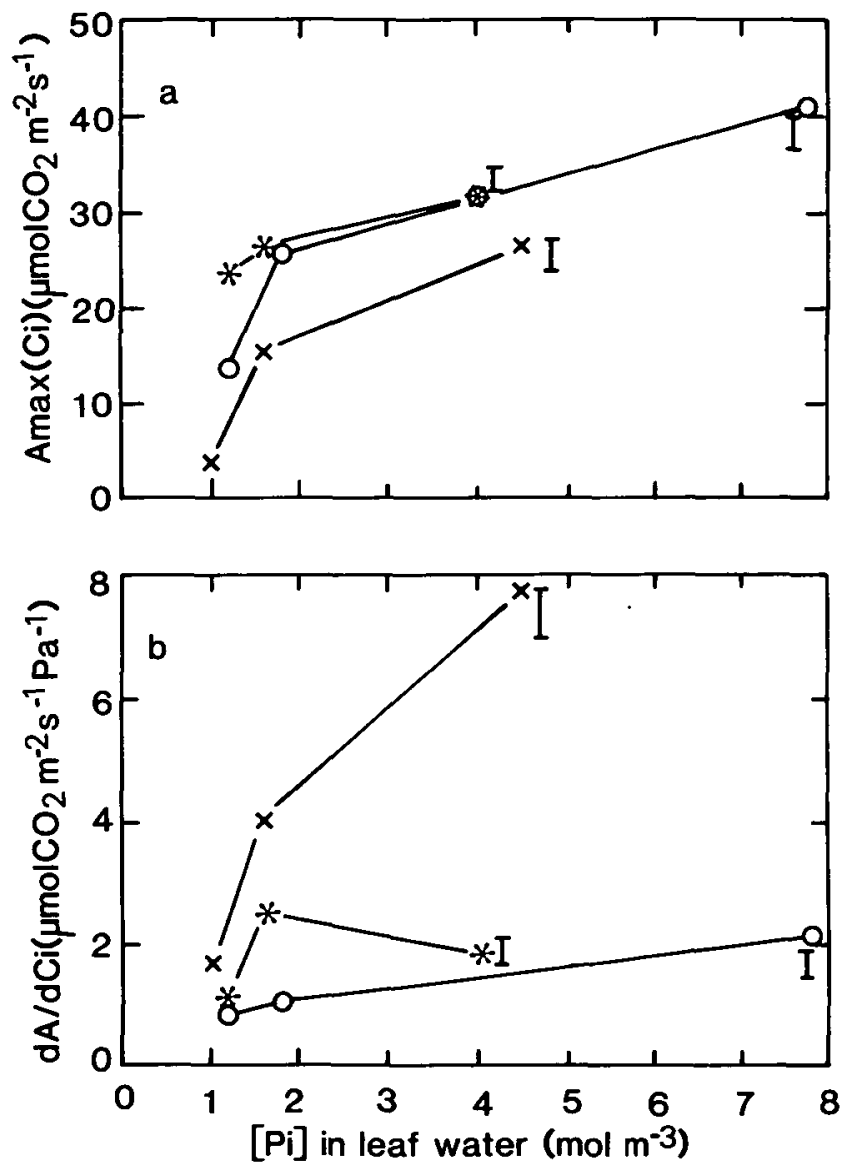

FIG. 3. Effect of the calculated Pi concentration in leaf water on the $\mathrm{CO}_{2}$ saturated photosynthetic rate, $A_{\max \left(\mathrm{C}_{3}\right)}$ (a) and carboxylation efficiency, $d A / d C_{\mathrm{i}}(\mathrm{b})$ in sunflower $(\mathrm{O})$, maize $(\mathrm{x})$ and wheat $(*)$. Bars indicate least significant difference between the means at $5 \%$ probability.

larly in photosynthesis and respiration ensures a critical role in all plant functions. Deficient phosphate, therefore, greatly affects the plant processes at subcellular, cellular and whole leaf (and other organ) levels of organization. The work described here is intended to assess the relative importance of particular structural and functional components of leaves in determining their photosynthetic competence when grown with a range of available phosphate. Growth of the three species studied was greatly decreased by phosphate deficiency and leaf area and dry matter per plant were reduced to similar extent (Table 2). Our data show that phosphate deficiency significantly altered the photosynthetic characteristics of leaves, decreasing the maximum rates of both $\mathrm{CO}_{2}$ and light saturated photosynthetic rates (Figs $3 a, 5 a$ ), the carboxylation efficiency (Fig. 3b) and the apparent quantum yield for $\mathrm{CO}_{2}$ assimilation (Fig. 5b). In this we substantiate the observations made by Brooks (1986), Lauer et al. (1989) and Rao and Terry (1989). Leaf area and shoot dry matter per plant were more sensitive to phosphate deficiency than photosynthetic rate per unit leaf area. Similar observation was made in different species (Bouma,
1983; Rao and Terry, 1989). In addition, we show that the decreased photosynthetic capacity of leaves with inadequate phosphate was determined mainly by mesophyll factors and not by decreased stomatal conductance and restricted $\mathrm{CO}_{2}$ diffusion.

\section{Phosphorus in leaf tissue and cells}

Leaves grown under phosphate deficiency accumulated small amounts of phosphate per unit area of leaf (Table 2) with between 1 and $2 \mathrm{mmol}$ of total phosphate $\mathrm{m}^{-2}$ and about one-tenth of this was inorganic phosphate when

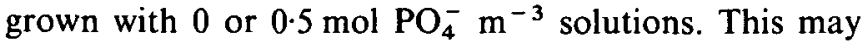
be considered the minimum amount of phosphate which allows a leaf to develop and function. With greater phosphate supply $\left(10 \mathrm{~mol} \mathrm{~m}^{-3}\right)$, the amount of phosphate accumulated per unit leaf area increased in all species, rather more in sunflower than wheat or maize. Clearly the phosphate content per $\mathrm{m}^{2}$ leaf was smaller in maize than in sunflower or wheat. However, when expressed as concentration of $\mathrm{Pi}$ in leaf water, the minimum concentration was similar in the three species. At greater phosphate supply, however, sunflower did accumulate greater amounts of Pi in the tissue water than wheat or maize. It is generally considered that the average concentration of phosphate in the tissue is about $9 \cdot 0 \mu \mathrm{mol} \mathrm{g}^{-1}$ fresh weight (Bieleski and Ferguson, 1983). In the present studies this concentration was $7.5,3.5$ and $4.9 \mu \mathrm{mol} \mathrm{g}^{-1}$ fresh weight (of leaf) in the phosphate deficient leaves of sunflower, maize and wheat, respectively. Phosphate ions in the cell are distributed into different compartments, namely vacuole, cytosol and organelles. About 85 to $95 \%$ of the total Pi present in the cell is considered to be in the inactive (non-metabolic) pool and the rest in the active (metabolic) pool (Bieleski, 1973). The metabolic pool represents the $\mathrm{Pi}$ in the cytoplasm and organelles and in an actively photosynthesizing cell there exists a dynamic equilibrium between the active pool of $\mathrm{Pi}$ in the cytoplasm and chloroplasts. Hence a minimum concentration of $\mathrm{Pi}$ in the tissue water is essential to maintain the functional capability of the leaf. In the present investigation this concentration in the leaf water was about 1 to $1.2 \mathrm{~mol} \mathrm{Pi} \mathrm{m} \mathrm{m}^{-3}$ or 0.1 to $0.2 \mathrm{mmol} \mathrm{Pi} \mathrm{m}^{-2}$ leaf area (Table 2).

To achieve the very small phosphate contents in leaf tissue, it was necessary to grow the plants under extreme phosphate deficiency. The effect on size and growth of the plants was much greater than on the phosphate content of the leaf. For instance the leaf area per plant was reduced by $95 \%$ and shoot dry matter by $93 \%$ (Table 1) but the total leaf phosphate content was reduced by only $75 \%$ (Table 2 ) in low-phosphate-grown sunflower. The results were also similar in the other two species. Hence, the mechanisms for maintaining the cellular phosphate status is much more effective than those determining growth. 

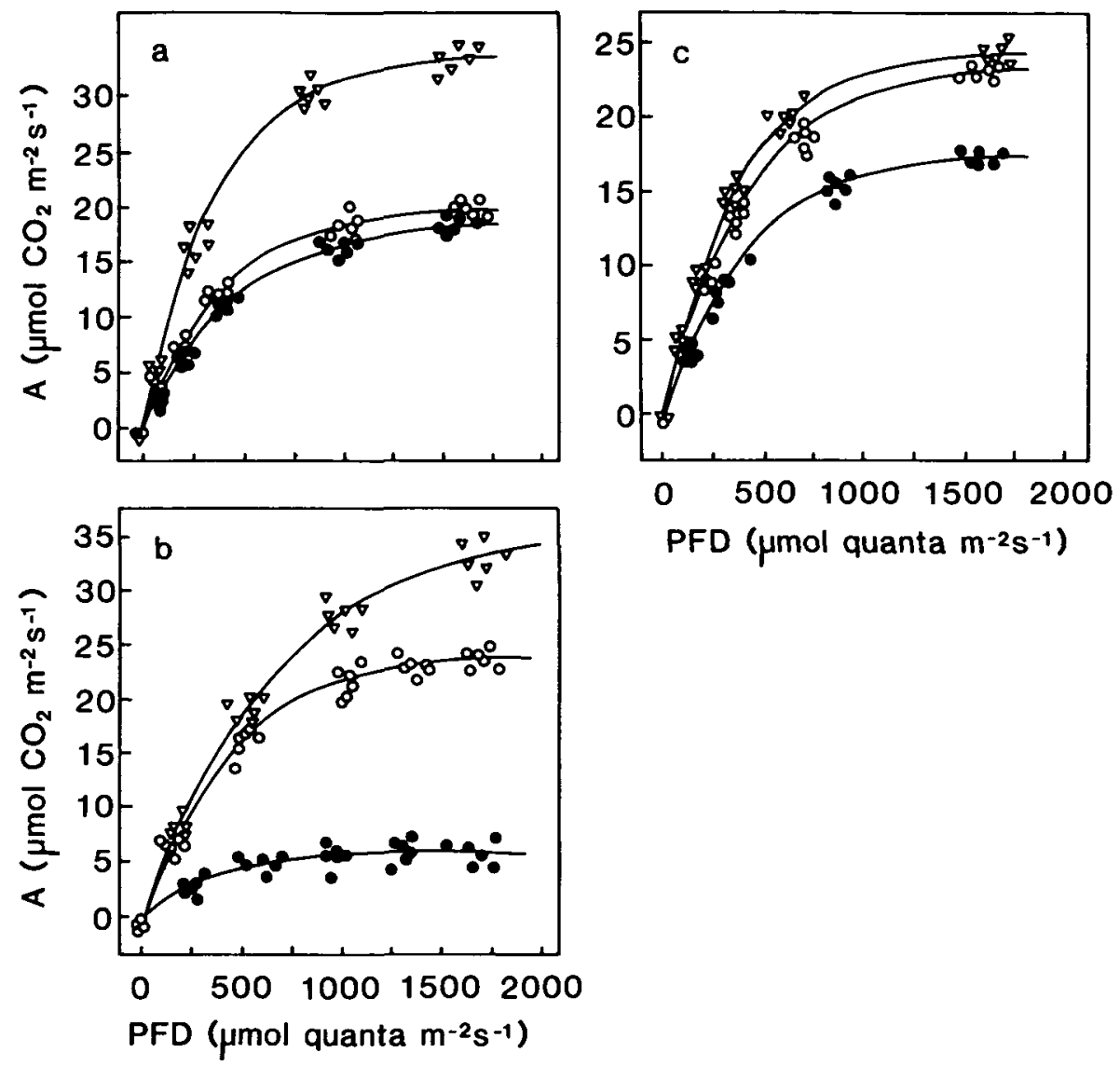

Fig. 4. Light response curves of sunflower (a), maize (b) and wheat (c) plants grown with $10(\nabla), 0.5(O)$ and $0(\bullet) \mathrm{mol}^{-3}$ phosphate concentrations. All curves are of the form $y=a+b r^{x}$ and the $R^{2}$ values in percentage in the respective phosphate treatments were 97,95 and 98 in sunflower, 97, 98 and 86 in maize and 94,96 and 98 in wheat.

TA B LE 4. Relative stomatal and mesophyll limitations of photosynthesis in sunflower, maize and wheat plants grown with different levels of phosphate nutrition

Each value is an average of 4-6 readings, s.e. of the mean is given in parenthesis.

\begin{tabular}{llll}
\hline $\begin{array}{l}\text { Concentration of } \mathrm{PO}_{4}^{-} \text {in } \\
\text { the solution }\left(\mathrm{mol} \mathrm{m}^{-3}\right)\end{array}$ & $\begin{array}{l}\text { Relative stomatal } \\
\text { limitation } \\
(\%)\end{array}$ & \multicolumn{2}{l}{ Relative mesophyll limitation } \\
\cline { 2 - 3 } & & $\begin{array}{l}\text { at } C_{\mathrm{i}}=34 \mathrm{~Pa} \\
(\%)\end{array}$ & $\begin{array}{l}\text { at saturating } C_{\mathrm{i}} \\
(\%)\end{array}$ \\
\hline $\begin{array}{l}\text { Sunflower } \\
10.0\end{array}$ & $17(3)$ & 0 & 0 \\
0.5 & $14(4)$ & $32(5)$ & $40(4)$ \\
0.0 & $19(3)$ & $45(5)$ & $69(4)$ \\
Maize & & & \\
10.0 & $6(3)$ & 0 & 0 \\
0.5 & $4(3)$ & $32(4)$ & $81(6)$ \\
0.0 & $4(3)$ & $65(7)$ & $87(6)$ \\
& & & \\
Wheat & $17(6)$ & 0 & 0 \\
10.0 & $16(4)$ & $8(2)$ & $20(4)$ \\
0.5 & $19(8)$ & $21(7)$ & $22(5)$ \\
0.0 & & & \\
\hline
\end{tabular}

Leaf composition in relation to phosphate supply

Effects of phosphate deficiency were similar in the two $\mathrm{C}_{3}$ and one $\mathrm{C}_{4}$ species: small decrease in fresh mass per unit leaf area, production of smaller cells and, therefore, more cells per unit area (Table 3). Consequently, the cell surface to leaf surface area $\left(A_{\text {mes }} / A_{\text {leaf }}\right)$ was greater in phosphate deficient than phosphate sufficient sunflower and maize, but not in wheat. Assuming spherical cells 

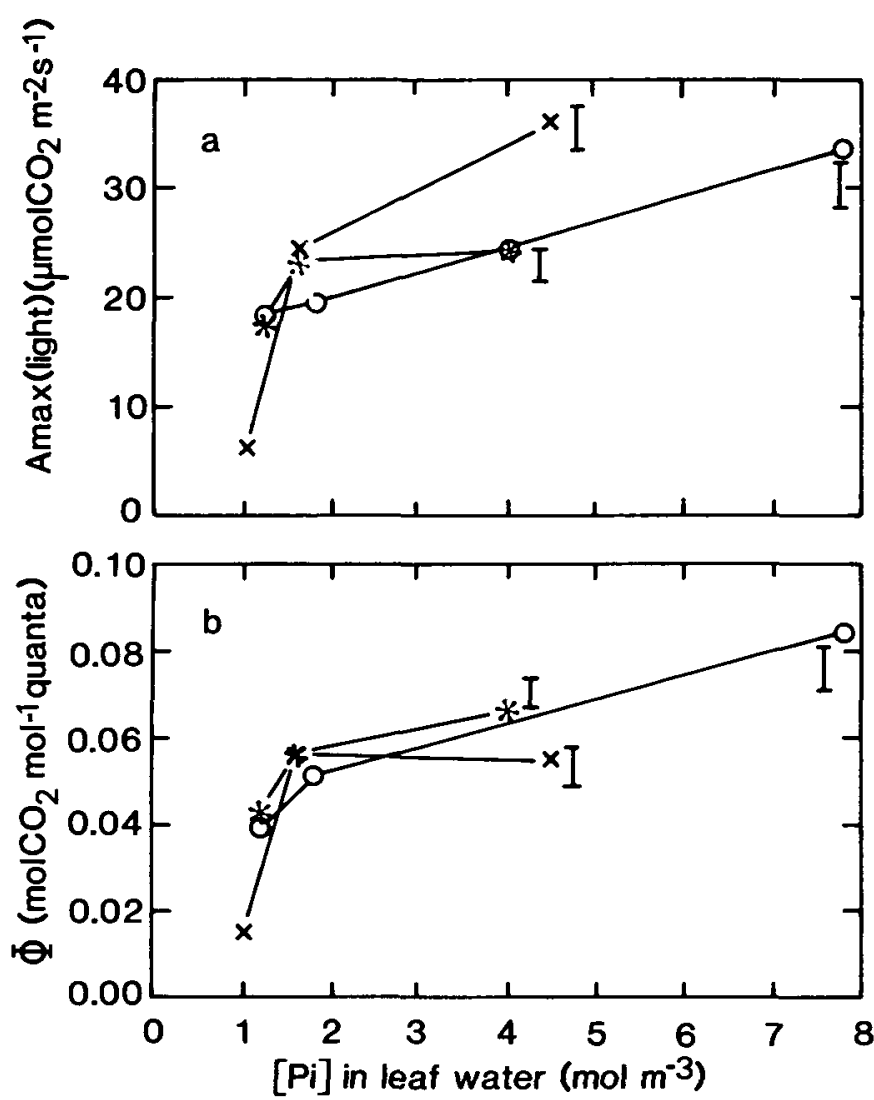

FIG. 5. Effect of the calculated Pi concentration in leaf water on the light saturated photosynthetic rate, $A_{\max (1 \mathrm{gght})}$ (a) and apparent quantum yield for $\mathrm{CO}_{2}$ assimilation, $\phi(b)$ in sunflower $(O)$, maize $(x)$ and wheat (*). Bars indicate least significant difference between the means at $5 \%$ probability.

and that the mass is uniformly distributed throughout the cell population, Lawlor et al. (1989) calculated $A_{\text {mes }} /$ $A_{\text {leaf }}$ ratios ranging from 16 (high N supply) to 22 (low $\mathrm{N}$ supply) for wheat. In the present investigations this ratio was not significantly different in phosphate deficient and phosphate sufficient (13 compared to 13.6) wheat leaves. Smaller $A_{\text {mes }} / A_{\text {leaf }}$ ratios are reported in wheat by Parker and Ford (1982) and Deane and Leech (1982). In our study, sunflower had ratios of 34 in phosphate deficient and 31.5 in phosphate sufficient leaves because of the much smaller cell volume and hence greater number of cells per unit leaf area compared to wheat or maize. A result of these changes is that the cell surface area would not provide a greater physical barrier to $\mathrm{CO}_{2}$ diffusion into cells with phosphate deficiency. On the contrary, a slightly increased $\mathrm{CO}_{2}$ diffusion might result if the metabolic alterations in the tissue do not alter the coefficient of diffusion of $\mathrm{CO}_{2}$ across the membranes or in cell compartments.

The effect of phosphate deficiency was to alter the composition of the tissue although the response depended on the species. Thus, the amount of chlorophyll per $\mathrm{m}^{2}$ of leaf area decreased with phosphate deficiency more in maize than in sunflower but was unaffected in wheat (Table 3). Also the amount of total soluble protein decreased with phosphate deficiency very markedly and almost to the same extent in sunflower and maize, but to a smaller extent in wheat. The chlorophyll to total soluble protein ratio increased with phosphate deficiency in sunflower and maize because of a greater reduction in soluble protein than in chlorophyll. Thus the effects of phosphate deficiency would be to decrease the metabolic capacity of the tissues, in as far as the maximum amount and rate of activity of enzymes etc. are related to the amount of protein and other components.

\section{Photosynthesis, stomatal conductance and phosphate supply}

The [Pi] in the tissue water strongly influenced the photosynthetic rate, $A$, and stomatal conductance, $g_{\mathrm{s}}$. A small decrease in $[\mathrm{Pi}]$ in the tissue water near the minimum values markedly decreased $A, g_{\mathrm{s}}, A_{\max \left(\mathrm{C}_{\mathrm{i}}\right)}$, and $A_{\max (\mathrm{ight})}$ in all the three species studied and we do not consider patchy stomatal closure was responsible. There was a similar effect on carboxylation efficiency and apparent quantum yield for $\mathrm{CO}_{2}$ assimilation. These results agree with the observations of Brooks (1986) and Lauer et al. (1989). At larger Pi content, the rate of change in these photosynthetic parameters was much smaller than at low Pi content. The $\mathrm{CO}_{2}$ (Fig. 2) and light (Fig. 4) compensation points were found to increase with phosphate deficiency in all three species studied.

In phosphate deficient plants both $A$ and $g_{\mathrm{s}}$ decreased, but the former was much more affected than the latter resulting in increased $C_{\mathbf{i}}$ (Fig. 1). This suggests that mesophyll factors were more sensitive to phosphate deficiency than stomatal factors and that the stomatal mechanism was not tightly coupled to the mesophyll to maintain constant $C_{\mathrm{i}}$. This would lead to a decrease in the water use efficiency of phosphate deficient plants. This contradicts the proportional changes observed in $A$ and $g_{s}$ by Wong, Cowan, and Farquhar (1985) in maize and soybean plants grown with different nutrient supply. However, the relative stomatal limitation of photosynthesis remained unaffected by phosphate deficiency in all the three species studied (Table 4). This shows $g_{s}$ to be of little importance in the reduction of $A$. Our data also show that stomatal limitation was smaller in maize than in sunflower and wheat at all levels of phosphate studied. Farquhar and Sharkey (1982) contradict the view of Körner, Scheel, and Bauer (1979) that stomata limit photosynthesis more in $\mathrm{C}_{4}$ species than in $\mathrm{C}_{3}$ species.

Lauer et al. (1989) indicated that mesophyll factors were more limiting to photosynthesis than were stomata in phosphate deficient soybean leaves. We found that the relative mesophyll limitation increased drastically with phosphate deficiency (although, as with the changes in structural composition, the magnitude depended on the 
species). The major reasons for the increased relative mesophyll limitation in phosphate deficient leaves are the reduced maximum potential rate of photosynthesis, reduced carboxylation efficiency and the reduced apparent quantum yield for $\mathrm{CO}_{2}$ assimilation. These reflect the structural and compositional changes in the leaf; the decrease in proteins and pigments, for example, decreases the inherent capacity of the $\mathrm{CO}_{2}$ fixing, light harvesting and energy transducing systems. The causes for these reductions will be considered in a further publication.

\section{ACKNOWLEDGEMENTS}

We thank Dr R. Mitchell for the useful discussions on curve fitting, Ms V. Mitchell and $\mathrm{Mr} \mathrm{A}$. Young for helping with measurements, $\mathrm{Mr} \mathrm{K}$. Plumb and $\mathrm{Mr} \mathrm{J}$. Franklin for growing the plants and Ms $\mathrm{H}$. Weir and Ms D. Hughes for producing the manuscript. The first author is a recipient of a Scholarship from the Association of Commonwealth Universities (London).

\section{LITERATURE CITED}

ARnON, D. I., 1949. Copper enzymes in isolated chloroplasts. Polyphenol oxidases in Beta vulgaris. Plant Physiology, 24, $1-15$.

BIEleski, R. L., 1973. Phosphate pools, phosphate transport and phosphate availability. Annual Review of Plant Physiology, 24, 225-52.

- and FERguson, I. B., 1983. Physiology and metabolism of phosphate and its compounds. In Encyclopedia of plant physiology, New series. Vol 15A. Eds A. Läuchli and R. L. Bieleski. Springer-Verlag, New York.

Bouma, D., 1983. Diagnosis of mineral deficiencies using plant tests. In Encyclopedia of plant physiology, New Series. Vol 15. Eds A. Läuchli and R. L. Bieleski. Springer-Verlag, Berlin.

Bradford, M. M., 1976. A rapid and sensitive method for the quantification of microgram quantities of proteins utilizing the principle of protein-dye binding. Analytical Biochemistry, 72, 248-54.

BROOKS, A., 1986. Effects of phosphorus nutrition on ribulose1,5-bisphosphate carboxylase activation, photosynthetic quantum yield and amounts of some Calvin cycle metabolites in spinach leaves. Australian Journal of Plant Physiology, 13, 221-37.

Clarkson, D. T., and Hanson, J. B., 1980. The mineral nutrition of higher plants. Annual Review of Plant Physiology, 31, 239-98.

Deane, C., and LeECH, R. M., 1982. Genome expression during normal leaf development. 2. Direct correlation between ribulose bisphosphate carboxylase content and nuclear ploidy in a polyploidy series of wheat. Plant Physiology, 70, 1605-8.

EDWARDS, G. E., and WALKer, D. A., 1983. In $C_{3}, C_{4}$ : mechanisms and cellular and environmental regulation of photosynthesis. Blackwell Scientific Publications Ltd., Oxford.
Farquhar, G. D., and Sharkey, T. D., 1982. Stomatal conductance and photosynthesis. Annual Review of Plant Physiology, 33, 317-45.

HeldT, H. W., and Rapley, L., 1970. Specific transport of inorganic phosphate, 3-phosphoglycerate and dihydroxy-acetone phosphate and of dicarboxylate across the inner membrane of spinach chloroplasts. FEBS Letters, 10, 143-8.

Kitson, R. E., and Mellon, M. G., 1944. Colorimetric determination of phosphorus as molybdinando-phosphoric acid. Industrial and Engineering Chemistry, 16, 379-83.

KöRNER, CH., Scheel, J. A., and BaUER, H., 1979. Maximum leaf diffusive conductance in vascular plants. Photosynthetica, $13,45-82$.

KU, S., and EDwards, G., 1987. Oxygen inhibition of photosynthesis. II. Kinetic characteristics as affected by temperature Plant Physiology, 59, 991-9.

Lauer, M. J., Pallardy, S. G., Blevins, D. G., and Randall, D. D., 1989. Whole leaf carbon exchange characteristics of phosphate deficient soybeans. Ibid. 91, 848-54.

LaWlor, D. W., Kontturi, M., and Young, A. T., 1989. Photosynthesis by flag leaves of wheat in relation to protein, ribulose bisphosphate carboxylase activity and nitrogen supply. Journal of Experimental Botany, 40, 43-52.

MÄCHLER, F., SCHNYDER, H., and NöSBERGER, J., 1984. Influence of inorganic phosphate on photosynthesis of wheat chloroplasts. I. Photosynthesis and assimilate export. Ibid. 35, 481-7.

PARKer, M. L., and Ford, M. A., 1982. The structure of the mesophyll of flag leaves in three Triticum species. Annals of Botany, 49, 165-76.

RAO, M., and TERRY, N., 1989. Leaf phosphate status, photosynthesis and carbon partitioning in sugar beet. I. Changes in growth, gas exchange and Calvin cycle enzymes. Plant Physiology, 90, 814-19.

Sivak, M. N., and Walker, D. A., 1986. Photosynthesis in vivo can be limited by phosphate supply. New Phytologist, 102, $499-512$.

Stitt, M., Huber, S., and Kerr, P., 1987. Control of photosynthetic sucrose formation. In The biochemistry of plants. A comprehensive treatise, Vol 10. Eds M. D. Hatch and N. K. Broadman. Academic Press, New York. Pp. 327-409.

TERrY, N., and Ulrich, A., 1973. Effects of phosphorus deficiency on the photosynthesis and respiration of leaves of sugar beet. Plant Physiology, 51, 43-7.

Walker, D. A., and Sivak, M. N., 1985. Can phosphate limit photosynthetic carbon assimilation in vivo? Physiologia Végétale, 23, 829-41.

WiLlis, A. J., and JefFERIES, R. L., 1963. Investigating on the water relations of sand-dune plants under natural conditions. In The water relations of plants. Eds $\mathbf{A}$. J. Rutter and $\mathbf{F}$. $\mathbf{H}$. Whitehead. Blackwell Scientific Publications, London. Pp. 174-5.

Wong, S. C., Cowan, I. R., and Farquhar, G. D., 1985. Leaf conductance in relation to rate of $\mathrm{CO}_{2}$ assimilation. I. Influence of nitrogen nutrition, phosphate nutrition, photon flux density and ambient partial pressure of $\mathrm{CO}_{2}$ during ontogeny. Plant Physiology, 78, 821-5. 